\title{
EKSPLOITAS1 SEKSUAL ANAK PERSFEKTIF -UNDANG UNDANG PERLINDUNGAN ANAK SEBAGAIMANA TELAH DIUBAH DENGAN UNDANG UNDANG NOMOR 35 TAHUN 2014 DAN PERUBAHAN KEDUA UNDANG UNDANG NOMOR 17 TAHUN 2016
}

\author{
Oleh: Mujiburrahman, S.H.,M.H. \\ (Dosen Fakultas Hukum Universitas Tamansiswa Palembang) \\ Email : mujiburrahman7272@gmail.com
}

\begin{abstract}
ABSTRAK
Eksploitasi anak di bidang seksual sudah sangat memprihatinkan, anak-anak menjadi objek seksual atau anak sebagai korban. Bentuk bentuk eksploitasi terhadap anak, yaitu pelacuran anak, pornografi anak anak maupun melalui perdagangan orang (trafiking) terhadap anak-anak untuk tujuan seksual.

Perlindungan terhadap eksploitasi anak di bidang seksual diatur diantaranya Kitab Undang Undang Hukum Pidana, Undang Undang Nomor 23 Tahun 2004 tentang Kekerasan Dalam Rumah Tangga, Undang-Undang Nomor 21 Tahun 2007 tentang Perdagangan Orang, Undang Undang Nomor 4 Tahun 2008 tentang Pornografi, dan secara khusus diatur dalam UU Nomor 23 Tahun 2002 tentang Perlindungan Anak yang telah diubah dengan Undang-Undang Nomor 35 Tahun 2004 dan Undang-Undang Nomor 17 Tahun 2016;

Eksploitasi Anak di bidang Seksual merupakan kekerasan terhadap Anak, UndangUndang Nomor 23 Tahun 2002 tentang Perlindungan Anak sebagaimana telah diubah dengan Undang-Undang Nomor 35 Tahun 2004 dan Undang-Undang Nomor 17 Tahun 2016 mengatur sanksi pidananya pada Pasal 81, 81 A, 82, 82 A dan 88.
\end{abstract}

Kata Kunci : , Exploitasi Sexual, Anak-Anak, Perlindungan Hukum.

\section{A. Latar Belakang}

Anak merupakan amanah dari Allah SWT yang dititipkan kepada umatnya yang dipercaya akan mampu menjaga, merawat sehingga anak dapat tumbuh dan berkembang menjadi harapan keluarga, bangsa dan negara. Sebagai harapan keluarga, bangsa dan negara maka anak mendapatkan perhatian khusus dari negara, diberikan perlindungan hukum.

Keseriusan negara memberikan perlindungan hukum kepada anak telah melahirkan Peraturan perundang-undangan yang khusus yaitu; Undang-Undang No. 23 tahun 2002 sebagaimana telah diubah dengan Undang-Undang Nomor : 35 tahun 2014, kemudian 
diubah dengan Undang-Undang Nomor 17 tahun 2016 tentang perlindungan anak. Selain itu negara sebelumhya telah menerbitkan Undang-Undang N0. 11 Tahun 2012 tentang sistem peradilan anak sebagai hukum formal, yaitu mengatur proses peradilan pidana anak mulai dari penyidikan, penuntutan, pemeriksaan di pengadilan sampai pada anak tempat menjalankan putusan Pengadilan di Lembaga Pembinaan Khusus Anak (LPKA).

Anak-anak banyak menjadi korbak Eksploitasi, . beberapa bentuk eksploitasi terhadap anak sebagiamana dimuat dalam Undang-Undang Nomor 23 tahun 2002 tentang perlindungan anak, yaitu : Eksploitasi Fisik, Eksploitasi konomi dan Eksploitasi sexual.

Ketentuan pemberian perlindungan terhadap anak di Indonesia tidak terlepas dari Konvensi PBB tentang Anak (The Convention on The Rights of The Child) yang meliputi a. nondiskriminasi, b. kepentingan terbaik bagi anak, c. Hak untuk hidup, kelangsungan hidup dan perkembangan dan, c. penghargaan terhadap pendapat anak.

Pasal 1 ayat 1 UU RI No. 23 Tahun 2002 mendefinisikan anak adalah seseorang yang belum berusia 18 (delapan belas) tahun, termasuk anak yang masih dalam kandungan. Sedangkan dalam berbagai peraturan perundang-undangan Indonesia, tidak terdapat pengaturan yang tegas terhadap batasan usia untuk anak seperti: diatur dalam Pasal 330 Kitab Undang Undang Hukum Perdata menentukan bahwa belum dewasa apabila belum mencapai usia 21 (dua puluh satu) tahun dan tidak lebih dahulu telah menikah, Pasal 7 UU No. 1 Tahun 1974 tentang Perkawinan, pemberian izin perkawinan kepada pihak pria yang telah berusia 19 (sembilan belas) tahun dan wanita telah berusia 16 (enam belas) tahun, Pasal 2 UU No. 4 Tahun 1979 tentang Kesejahteraan Anak batasannya seorang yang belum mencapai usia 21(dua puluh satu) tahun dan belum pernah menikah; 
Dalam lingkup pengasuhan terhadap anak baik oleh orang tua, wali atau pihak lain yang bertanggungjawab atas pengasuhan anak, maka pada ketentuan Pasal 13 UU RI No. 23 Tahun 2002 tentang Perlindungan Anak bahwa hak anak mendapatkan perlindungan dari perlakuan:
a. Diskriminasi
b. Eksploitasi baik ekonomi maupun seksual;
c. Penelantaran;
d. Kekejaman, kekerasan dan penganiayaan;
e. Ketidakadilan;
f. Perlakuan salah lainnya

Berkaitan dengan eksploitasi anak di bidang ekonomi dan seksual pada penjelasan Pasal 13 tersebut diatas, bahwa perlakuan eksploitasi tersebut dilakukan misalnya dengan tindakan atau perbuatan memperalat, memanfaatkan atau memeras anak untuk memperoleh keuntungan pribadi, keluarga atau golongan.

Pengertian mengenai eksploitasi anak baik ekonomi dan seksual berupa kekerasan terhadap anak baik fisik, psikis maupun di bidang pekerjaan, hal tersebut dapat dilihat pada penjelasan pada Pasal 66 perubahan pertama UU Perlindungan Anak yaitu UU No. 35 Tahun 2014 menyebutkan yang dimaksud dengan dieksploitasi secara ekonomi merupakan tindakan yang bertujuan untuk mendapat keuntungan material dengan atau tanpa persetujuan Anak yang menjadikan anak sebagai korban dari tindakan yang meliputi pelacuran, kerja atau pelayanan paksa, perbudakan, penindasan, pemerasan, pemanfaatan fisik, seksual, organ reproduksi, melakukan transplantasi organ dan/atau jaringan tubuh. Sedangkan secara seksual merupakan tindakan yang memanfaatkan organ 
tubuh anak untuk mendapatkan keuntungan tidak terbatas pada hanya pada kegiatan berupa pelacuran dan pencabulan.

Faktor penyebab dari eksploitasi seks komersial anak sangatlah kompleks dan setiap negara berbeda satu sama lain, tetapi secara umum disebabkan karena faktor kemiskinan, pendapatan keluarga yang rendah atau sebaliknya relatif tinggi, faktor budaya berupa kewajiban untuk membantu kehidupan keluarga, disfungsi keluarga, menurunnya nilainilai termasuk nilai-nilai dalam pendidikan.

\section{B. Rumusan Masalah}

1. Bagaimanakah perlindungan hukum terhadap Eksploitasi Anak dibidang Seksual ?

2. Apakah Sanksi Pidana terhadap pelaku tindak pidana eksploitasi seksual anak ?

\section{PEMBAHASAN}

\section{Perlindungan Hukum Terhadap Eksploitasi Anak Dibidang Seksual Persfektip}

\section{Undang-Undang Perlindungan Anak}

Kekerasan anak di Indonesia mendapatkan perhatian khusus dari Komite Konvensi Hak Anak, pada tanggapan Komite terhadap laporan dari pemerintah Indonesia menyatakan bahwa tingginya jumlah anak yang menjadi korban kekerasan, pelecehan dan diterlantarkan, termasuk pelecehan seksual di sekolah, tempat-tempat umum dan di tempat-tempat penahanan serta dalam keluarga, selain itu penghukuman fisik sebagai salah satu bentuk kekerasan terhadap anak masih di praktekan secara meluas, diterima secara budaya dan sah menurut hukum. ${ }^{1}$

Salah satu cara mengatasi, pemerintah Indonesia menerbitkan peraturan peraturan yang melarang dan memberikan sanksi berat terhadap pelaku tindak pidana eksploitasi anak. Aturan yang melarang tersebut tersebar dalam beberapa undang-

\footnotetext{
${ }^{1}$ Anak Republik Inonesia No. 02 Tahun 2011 tentang Pedoman Anak Korban Kekerasan.
} 
undang, yaitu UU No. 4 Tahun 2008 tentang Pornografi dan UU No. 21 Tahun 2007 tentang Perdagangan Orang dan terakhir dalam UU No. 23 Tahun 2002 tentang Perlindungan Anak sebagaimana telah diubah dengan UU No. 35 Tahun 2004 dan UU No. 17 tahun 2016.

Undang-Undang Perlindungan Anak tidak mendefinisikan pengertian eksploitasi anak, hanya menggolongkan eksploitasi menjadi dua yaitu eksploitasi seksual dan ekonomi. Dengan mempergunakan pengertian seksual menurut UU No. 21 tentang Perdangangan orang, diatur pada Pasal 1 ayat 8 menyatakan bahwa eksploitasi seksual merupakan pemanfaatan organ tubuh seksual atau organ tubuh lainnya yang bertujuan untuk mendapat keuntungan dari korban, yang pemanfaatan tersebut tidak terbatas pada semua kegiatan pelacuran dan pencabulan.

Dari pengertian tersebut bahwa eksploitasi seksual menurut hukum positif Indonesia mempunyai pengertian yang sangat luas, dalam kaitan terhadap anak merupakan kekerasan seksual terhadap anak, sebab hal tersebut melanggar hak anak untuk tumbuh dan berkembang dan hak untuk mendapat perlindungan dari tindakan kekerasan baik secara fisik dan psikis.

Kekerasan seksual anak dilakukan dengan cara mengeksploitasi seksual anak berupa anak dijadikan objek untuk pariwisata seks, beberapa kasus perkawinan anak atau dengan cara-cara lain seperti perbudakan dalam rumah dalam hal ini majikan mengontrak anak tetapi terhadap anak dimanfaatkan untuk tujuan seksual. ${ }^{2}$

Menurut End Child Prostitution, child Pornography and the Trafficking of Children for Sexual Purpose (ECPAT) bentuk-bentuk lain yang terkait dengan

2 https://satunothingimposible.wordpress.com, Eksploitasi Seks Komersial Anak (ESKA), diunduh 18 Oktober 2020 
eksploitasi seksual komersial anak adalah pelacuran anak, pornografi anak dan perdagangan anak untuk tujuan seksual. ${ }^{3}$

Eksploitasi Seksual Komersial Anak (ESKA) hendaknya dibedakan dengan perdagangan orang karena ada perbedaan meskipun perdagangan orang dalam hal ini anak ada ditujukan untuk tujuan eksploitasi seksual komersial anak. Ketentuan pada Pasal 297 KUHP memberikan larangan perdagangan wanita dan perdagangan anak laki-laki yang belum dewasa dengan ancaman pidana paling lama enam tahun. Dengan demikian ada perbedaan unsur-unsur mengenai perdagangan orang dengan eksploitasi seksual komersial anak. Sedangkan dalam UU No. 21 Tahun 1997 tentang Pemberantasan Tindak Pidana Perdagangan Orang sebagai ketentuan khusus hanya memberikan definisi mengenai perdagangan orang, tetapi tidak memberikan pengertian tetang perdagangan anak.

Pemberian perlindungan terhadap anak justru untuk lebih memperhatikan lingkungan anak itu sendiri yaitu rumah, sekolah dan lingkungan sehari-hari. Untuk mengawasi tersebut prilaku orang-orang di sekitar anak adalah dengan melibatkan masyarakat sekitarnya. Keterlibatan masyarakat diatur berdasarkan Pasal 72 Undang Undang Perlindungan Anak yang mengatur mengenai peran serta masyarakat yang dapat dilakukan perorangan maupun lembaga. Dalam hal lembaga adalah lembaga yang aktivitasnya bergerak di bidang perlindungan anak, lembaga kemasyarakatan, lembaga sosial masyarakat, lembaga pendidikan, lembaga keagamaan termasuk media massa. 
Undang-undang mengamanatkan membentuk lembaga untuk memberikan perlindungan anak sampai tingkat daerah, hal tersebut diatur pada Pasal 74 UndangUndang tentang Perlindungan Anak, yaitu:

(1) Dalam rangka meningkatkan efektivitas pengawasan penyelenggaraan pemenuhan Hak Anak, dengan Undang-Undang ini dibentuk Komisi Perlindungan Anak Indonesia yang independen.

(2) Dalam hal diperlukan, Pemerintah Daerah dapat membentuk Komisi Perlindungan Anak Daerah atau lembaga lainnya yang sejenis untuk mendukung pengawasan penyelenggaraan Perlindungan Anak di daerah.

Ketentuan diatas ditindaklanjuti dengan Keputusan Presiden RI No. 77 Tahun 2003 tentang Komisi Perlindungan Anak Indonesia, dengan Keppres ini berdirilah KPAI yang tugasnya telah diatur dalam Pasal 76 Undang-Undang Perlindungan Anak, yaitu:

a. Melakukan pengawasan terhadap pelaksanaan perlindungan dan pemenuhan Hak Anak;

b. Memberikan masukan dan usulan dalam perumusan kebijakan tentang penyelenggaraan Perlindungan Anak.

c. Mengumpulkan data dan informasi mengenai Perlindungan Anak;

d. Menerima dan melakukan penelaahan atas pengaduan Masyarakat mengenai pelanggaran HakAnak;

e. Melakukan mediasi atas sengketa pelanggaran Hak Anak;

f. Melakukan kerja sama dengan lembaga yang dibentuk Masyarakat di bidang Perlindungan Anak dan 
g. Memberikan laporan kepada pihak berwajib tentang adanya dugaan pelanggaran terhadap Undang-Undang ini.”

Selain itu terhadap Anak yang mengalami eksploitasi seksual berhak meminta hak restitusi (ganti kerugian) dari pelaku tindak pidana. Hal ini diatur dalam Pasal 71D Undang Undang Perlindungan Anak:

(1) Setiap Anak yang menjadi korban sebagaimana dimaksud dalam Pasal 59 ayat (2) huruf b, huruf d, huruf h, huruf I dan huruf j berhak mengajukan ke pengadilan berupa hak atas restitusi yang menjadi tanggung jawab pelaku;

(2) Ketentuan lebih lanjut mengenai pelaksanaan restitusi sebagaimana dimaksud pada ayat (1) diatur dengan Peraturan Pemerintah.

Pemberian perlindungan terhadap korban eksploitasi anak dilakukan dengan beberapa cara sebagaimana diatur dalam undang-undang Perlindungan Anak, selain dengan memperberat sanksi pidana guna memberikan efek jera pada pelaku, juga dengan memberikan langkah-langkah yang lebih konkrit dengan mengembalikan atau memulihkan tidak saja fisik yang lebih penting dalam eksploitasi seksual adalah pemulihan secara psikis dan sosial.

Pemulihan terhadap anak korban eksploitasi seksual diatur dalam Peraturan Menteri Negara Pemberdayaan Perempuan dan Perlindungan Anak Republik Indonesia Nomor 02 Tahun 2011 tentang Pedoman Penanganan Anak Korban Kekerasan. Berdasarkan ketentuan tersebut yang diatur pada Pasal 1 terhadap anak korban kekerasan termasuk dibidang eksploitasi seksual dengan pedoman: a.pelayanan indentifikasi, b. rehabilitasi kesehatan, c. rehabilitasi sosial, d. Pemulangan, e. bantuan hukum dan reintegrasi sosial. 
Anak juga mempunyai hak untuk mendapat bantuan hukum, agar hak-hak anak yang berkaitan dengan hukum dapat terlindungi, seperti pendampingan pada saat pemeriksaan di tingkat penyidikan, penuntutan dan pemeriksaan persidangan. Selain itu dengan perubahan pertama Undang-Undang Perlindungan Anak yaiut UU No. 35 Tahun 2014 anak dapat meminta hak restitusi (ganti rugi) terhadap pelaku tindak pidana.

Anak Korban eksploitasi seksual yang dikembalikan ke orang tuanya atau keluarga pengganti harus dipastikan dalam keadaan yang selamat dan aman untuk ditindaklanjuti agar dapat berintegrai dengan keluarga termasuk lingkungannya (sosial), pada proses ini Anak diupayakan untuk meningkatkan keberdayaannya agar dapat hidup "normal" dalam masyarakat. Pada reintegrasi sosial ini Korban Anak tetap berhak untuk mendapat konseling lanjutan, pengobatan lanjutan, pendampingan oleh tenaga sosial termasuk pendampingan hukum.

Dengan demikian apabila ada anak menjadi korban eksploitasi seksual, agar dapat memperoleh perlindungan hendaknya orang tua atau keluarga tidak merahasiakan atau menutupi karena dianggap sebagai aib keluarga, sebaliknya yang segera dilakukan adalah:

a. Melaporkan ke kepolisian dan meminta pengantar ke rumah sakit untuk pembuatan visum et repertum;

b. Memeriksakan anak ke dokter;

c. Menghubungi/melapor ke Komisi Perlindungan Anak Indonesia (KPAI);

d. Meminta bantuan hukum ke lembaga-lembaga swadaya masyarakat yang bergerak dibidang perlindungan anak seperti Lembaga Bantuan Hukum; 
e. Bersama KPAI dan lembaga swadya masyarakat agar hak-hak Anak Korban terpenuhi baik kesehatan, pemulihan baik fisik dan psikis yang berkesinambungan dari pusat pelayanan terpadu, dan kemungkinan meminta restitusi dari pelaku tindak pidana.

\section{Sanksi Pidana terhadap Pelaku Tindak Eksploitasi Anak di}

Pengaturan sanksi pidana mempunyai tujuan agar pelaku tindak pidana tidak mengulangi perbuatannya dan pada bagian lain adalah memberikan kepastian perlindungan masyarakat. Adanya sanksi pidana memberikan ancaman agar masyarakat tidak melakukan tindak pidana, berkaitan dengan sanksi pidana dalam rangka memberikan perlindungan terhadap anak Undang-Undang Perlindungan Anak telah mengalami dua kali perubahan dengan memperluas perbuatan yang diancam dengan sanksi pidana dan memperberat sanksi.

Perbuatan yang dikenakan sanksi pada Pasal 81 yaitu perbuatan yang diatur pada Pasal 76D yaitu melakukan kekerasan atau ancaman kekerasan memaksa Anak melakukan persetubuhan dengannya atau dengan orang lain)

Pasal 81 berbunyi:

1. Setiap orang yang melanggar ketentuan sebagaimana dimaksud dalam Pasal 76D dipidana dengan pidana penjara paling singkat 5 (lima) tahun dan paling lama 15 (lima belas) tahun dan denda paling banyak Rp5.000.000.000,00 (lima miliar rupiah);

2. Ketentuan pidana sebagaimana dimaksud pada ayat (1) berlaku pula bagi setiap orang yang dengan sengaja melakukan tipu muslihat, serangkaian kebohongan, atau membujuk Anak melakukan persetubuhan dengannya atau dengan orang

3. Dalam hal tindak pidana sebagaimana dimaksud pada ayat (1) dilakukan oleh orang tua, wali, orang-orang yang mempunyai hubungan keluarga, pengasuh anak, pendidik, 
tenaga kependidikan, aparat yang menangani perlindungan anak, atau dilakukan oleh lebih dari satu orang secara bersama-sama, pidananya ditambah 1/3 (sepertiga) dari ancaman pidana sebagaimana dimaksud pada ayat (1);

4. Selain terhadap pelaku sebagaimana dimaksud pada ayat (3), penambahan 1/3 (sepertiga) dari ancaman pidana juga dikenakan kepada pelaku yang pernah dipidana karena melakukan tindak pidana sebagaimana dimaksud dalam Pasal 76D;

5. Dalam hal tindak pidana sebagaimana dimaksud dalam Pasal 76D menimbulkan korban lebih dari 1 (satu) orang, mengakibatkan luka berat, gangguan jiwa, penyakit menular, terganggu atau hilangnya fungsi reproduksi, dan/atau korban meninggal dunia, pelaku dipidana mati, seumur hidup, atau pidana penjara paling singkat 10 (sepuluh) tahun dan paling lama 20 (dua puluh) tahun;

6. Selain dikenai pidana sebagaimana dimaksud pada ayat (1), ayat (3), ayat (4), dan ayat (5), pelaku dapat dikenai pidana tambahan berupa pengumuman identitas pelaku;

7. Terhadap pelaku sebagaimana dimaksud ayat (4) dan ayat (5) dapat dikenai tindakan berupa kebiri kimia dan pemasangan pendeteksi elektronik;

8. Tindakan sebagaimana dimaksud pada ayat (7) diputuskan bersama-sama dengan pidana pokok dengan memuat jangka waktu pelaksanaan tindakan;

9. Pidana tambahan dan tindakan dikecualikan bagi pelaku Anak.

Ketentuan Pasal 81 diatas selain memperberat sanksi pidana hingga ancaman hukuman mati, ketentuan pada ayat (4) pemberatan sanksi pidana terhadap pelaku yang mengulangi perbuatannya (residivis) yaitu penambahan 1/3 (sepertiga) dari ancaman pidana.

Ancaman hukuman mati diatur pada ayat (5), apabila korban lebih dari satu orang, mengalami luka berat, gangguan jiwa, penyakit menular, terganggu aau hilangnya fungsi 
alat reproduksi dan/atau korban meninggal dunia, ancamannya adalah hukuman mati, seumur hidup atau paling singkat 10 (sepuluh tahun) dan paling lama 20 (dua puluh) tahun.

Ketentuan yang baru ini bahwa ancaman pidana tidak saja bersifat perampasan kemerdekaan dan/atau denda, tetapi hal yang baru diatur pada ayat (6) dan ayat (7). Ayat (6) adalah mengatur pidana tambahan terhadap pelaku dengan cara mengumumkan pelaku pada media massa, hal ini berarti prilaku pelaku tindak pidana akan diketahui oleh orang banyak atau pidana ini bertujuan memalukan pelaku di masyarakat.

Ancaman pidana yang lebih ekstrim berupa kebiri dan pemasangan alat pendeteksi elektronik dalam jangka waktu tertentu. Hal tersebut diatur pada ayat (7) berisi ancaman sanksi pidana berupa kebiri secara kimia dan pemasangan alat deteksi elektronik terhadap pelaku tindak pidana, sehingga terhadap pelaku setelah menjalankan pidana penjara dapat diketahui keberadaannya.

Dengan demikian maka memperberat sanksi pidana terhadap pelaku tindak pidana seharusnya berorientasi agar pelaku dapat menjadi orang baik dan berguna, oleh karenanya penjatuhan sanksi pidana dengan pengumuman di meia massa, kebiri atau pemasangan alat pendeteksi elektronik hendaknya didasarkan dengan pertimbangan yang benar-benar dalam dan mempertimbangkan dari seluruh aspek, karena dapat saja berdampak buruk pada narapidana.

Pada penjatuhan sanksi pidana berupa kebiri seharusnya bukan sanksi yang bersifat retributif atau paksaan atau sebagai balas dendam dengan alasan pelaku jera atas perbuatannya. Dengan kebiri secara kimia tersebut adalah membuat disfungsi dari alat kelamin pelaku secara kimia dengan menekan hormon testoteron laki-laki, pada sisi lain dengan kebiri tersebut mempertimbangkan dampak negatif, karena dorongan nafsu 
banyak faktor penyebabnya seperti pengalaman pribadi yang tidak tergantung pada hormon testoteron, selain itu dengan kebiri kimia mempunyai periode waktu, sehingga apabila fungsi kimianya berakhir bisa saja keinginan melakukan hubungan seksual si penerima kebiri kimia akan lebih besar daripada sebelumnya, padehal ketentuan undangundang pada Pasal 81A bahwa kebiri kimia dilakukan terpidana bersamaan dengan rehabilitatif artinya dilakukan setelah pidana perampasan kemerdekaan dijalankan.

Ketentuan pada Pasal 82 mengatur sanksi pidana atas perbuatan yang dilarang pada Pasal 76E yaitu melakukan kekerasan atau ancaman kekerasan, memaksa, melakukan tipu muslihat, melakukan serangkaian kebohongan, atau membujuk Anak untuk melakukan atau membiarkan dilakukan perbuatan cabul.

Ketentuan Pasal 82 merubah dari ketentuan lama, yang mengancam sanksi pidana atas isinya menjadi sebagai berikut:

1. Setiap orang yang melanggar ketentuan sebagaimana dimaksud dalam Pasal $76 \mathrm{E}$ dipidana dengan pidana penjara paling singkat 5 (lima) tahun dan paling lama 15 (lima belas) tahun dan denda paling banyak Rp5.000.000.000,00 (lima miliar rupiah);

2. Dalam hal tindak pidana sebagaimana dimaksud pada ayat (1) dilakukan oleh orang tua, wali, orang-orang yang mempunyai hubungan keluarga, pengasuh anak, pendidik, tenaga kependidikan, aparat yang menangani perlindungan anak, atau dilakukan oleh lebih dari satu orang secara bersama-sama, pidananya ditambah $1 / 3$ (sepertiga) dari ancaman pidana sebagaimana dimaksud pada ayat (1);

3. Selain terhadap pelaku sebagaimana dimaksud pada ayat (2), penambahan $1 / 3$ (sepertiga) dari ancaman pidana juga dikenakan kepada pelaku yang pernah dipidana karena melakukan tindak pidana sebagaimana dimaksud dalam Pasal 76E; 
4. Dalam hal tindak pidana sebagaimana dimaksud dalam Pasal 76E menimbulkan korban lebih dari 1 (satu) orang, mengakibatkan luka berat, gangguan jiwa, penyakit menular, terganggu atau hilangnya fungsi reproduksi, dan/atau korban meninggal dunia, pidananya ditambah $1 / 3$ (sepertiga) dari ancaman pidana sebagaimana dimaksud pada ayat (1);

5. Selain dikenai pidana sebagaimana dimaksud pada ayat (1) sampai dengan ayat (4), pelaku dapat dikenai pidana tambahan berupa pengumuman identitas pelaku;

6. Terhadap pelaku sebagaimana dimaksud pada ayat (2) sampai dengan ayat (4) dapat dikenai tindakan berupa rehabilitasi dan pemasangan alat pendeteksi elektronik;

7. Tindakan sebagaimana dimaksud pada ayat (6) diputuskan bersama-sama dengan pidana pokok dengan memuat jangka waktu pelaksanaan tindakan;

8. Pidana tambahan dikecualikan bagi pelaku Anak.

Ketentuan Pasal 81 dan Pasal 82 dari sisi ancaman sanksi pidana adanya persamaan maupun perbedaan yang, dengan adanya persamaan ancaman sanksi pidana hal ini menunjukkan bahwa baik menyetubuhi dan berbuat cabul pada anak mempunyai dampak buruk yang sama pada anak. Persamaan sanksi pidana adalah:

1. Terhadap pelaku persetubuhan maupun perbuatan cabul diancam dengan pidana penjara paling singkat 5 (lima) tahun dan paling lama 15 (lima belas) tahun dan denda paling banyak Rp5.000.000.000,00 (lima miliar rupiah);

2. Dalam hal Pelaku persetubuhan maupun perbuatan cabul adalah orang tua, wali, orang-orang yang mempunyai hubungan keluarga, pengasuh anak, pendidik, tenaga kependidikan, aparat yang menangani perlindungan anak, atau dilakukan oleh lebih dari satu orang secara bersama-sama, pidananya ditambah 1/3 (sepertiga); 
3. Adanya pidana pemasangan alat deteksi elektronik terhadap pelaku tindak pidana persetubuhan maupun perbuatan cabul;

4. adanya pidana tambahan pelaku tindak pidana berupa pengumuman indentitas pelaku.

Antara Pasal 82 dan Pasal 83, disisipkan 1 (satu) pasal yakni Pasal 82A yang berbunyi sebagai berikut:

1. Tindakan sebagaimana dimaksud dalam Pasal 82 ayat (6) (dilaksanakan selama dan/atau setelah terpidana menjalani pidana pokok;

2. Pelaksanaan tindakan sebagaimana dimaksud pada ayat (1) di bawah pengawasan secara berkala oleh kementerian yang menyelenggarakan urusan pemerintahan di bidang hukum, sosial, dan kesehatan;

3. Ketentuan lebih lanjut mengenai tata cara pelaksanaan tindakan diatur dengan Peraturan Pemerintah.

Ketentuan yang secara khusus mengatur sanksi pidana terhadap pelaku eksploitasi seksual diatur pada Pasal 88, yang isinya adalah:

Setiap orang yang melanggar ketentuan sebagaimana dimaksud dalam Pasal 76I, dipidana dengan pidana penjara paling lama 10 (sepuluh) tahun dan atau denda paling banyak Rp. 200.000.000,- (dua ratus juta rupiah)

Ketentuan Pasal 88 tersebut ancaman sanksi pidana paling lama selama 10 (sepuluh) tahun tanpa ada ancaman pidana minimal, apabila dibandingkan dengan Pasal 81 dan 82 diatas yang ancamannya jauh lebih tinggi, hal ini menunjukkan bahwa tindak pidana yang diatur pada Pasal 88 berupa eksploitasi seksual terhadap anak dengan cara mempergunakan organ tubuh anak guna mendapat keuntungan dilakukan 
tanpa kekerasan, berbohong, tipu muslihat maupun membujuk, tetapi apabila dilakukan dengan cara kekerasan atau tipu muslihat, berbohong atau membujuk anak untuk besetubuh dengan diri sendiri atau orng lain maka pelaku tindak pidana dapat di ancam dengan Pasal 81 atau 82 apabila, misalnya anak tersebut dibohongi mau dipekerjakan dengan baik di restoran atau cafe, tetapi kemudian dijadikan pelacur untuk melayani tamu-tamu, maka perbuatan mengeksploitasi anak tersebut dapat diancam dengan Pasal 81 Undang Undang Perlindungan Anak.

Ketentuan Pasal 88 tersebut diatas mengancam agar siapapun tidak memanfaatkan atau mengeksploitasi anak baik berbuat cabul maupun bersetubuh, meskipun dilakukan tanpa ada kekerasan maupun dilakukan tanpa dengan kebohongan, tipu muslihat atau membujuk anak.

Dari ketentuan berupa ancaman sanksi pidana terhadap eksploitasi anak di bidang seksual baik berupa persetubuhan maupun perbuatan cabul, yang merupakan salah satu bentuk kekerasan terhadap anak. Perbuatan tersebut dilakukan dengan ancaman fisik maupun psikis, tipu muslihat dan sebagainya dalam pengertian tanpa persetujuan anak maupun orang tuanya atau walinya. karena eksploitasi seksual anak dapat dilakukan dengan banyak cara.

\section{KESIMPULAN}

1. Perlindungan Hukum Terhadap Eksploitasi Anak dibidang seksual pemerintah telah meratifikasi dan melahirkan beberapa Undang-Undang yaitu; Undang Undang Nomor 23 Tahun 2004 tentang Kekerasan Dalam Rumah Tangga, Undang-Undang Nomor 21 Tahun 2007 tentang Perdagangan Orang, Undang Undang Nomor 4 Tahun 2008 tentang Pornografi, dan secara khusus diatur dalam UU Nomor 23 Tahun 
2002 tentang Perlindungan Anak yang telah diubah dengan Undang-Undang Nomor 35 Tahun 2004 dan Undang-Undang Nomor 17 Tahun 2016;

2. Sanksi Pidana terhadap Pelaku Tindak Eksploitasi Anak di atur dalam UndangUndang Nomor: 23 Tahun 2002 tentang Perlindungan Anak sebagaimana telah diubah dengan Undang-Undang Nomor 35 Tahun 2004 dan Undang-Undang Nomor; 17 Tahun 2016 mengatur sanksi pidananya pada Pasal 81, 81 A, 82, 82 A dan 88.

\section{DAFTAR PUSTAKA}

\section{A. Buku-Buku}

Badan Penelitian dan Pengembangan HAM Kementerian Hukum dan HAM, Kompilasi Hasil Seminar Perlindungan Hukum dan HAM terhadap Anak Korban Eksploitasi Seks Komersial, 2014, Pohon Cahaya, Jakarta;

Bambang Purnomo, Asas-Asas Hukum Pidana, 1983, Ghalia Indonesia, Jakarta;

Barda Nawawi Arief, Bunga Rampai Kebijakan Hukum Pidana,1996, PT. Citra Aditya Bakti, Bandung;

Esthi Susanti Hudiono, Perlindungan Anak dari Eksploitasi Seksual di Kota Surabaya - Sebuah Perpektif Organisasi Masyarakat Sipil, 2014, CV Aswaja Pressindo, Surabaya

H. Dadang Hawari, Kekerasan Seksual Anak, 2013, Penerbit Universitas Indonesia, Jakarta, hlm. 138

Maidin Gultom, Perlindungan Hukum terhadap Anak - Dalam sistem Peradilan Pidana Anak di Indonesia, Refika Aditama, Bandung, 2014;

Marihot D. Saing dan Mujiburrahman, Sistem Peradilan Pidana Anak Di Indonesia, NoerFikri, Palembang, 2019;

Purnadi Purbacaraka dan Soerjono Soekanto, Sendi-Sendi Ilmu Hukum dan Tata Hukum, 1985, Alumni, Bandung;

R. Soesilo, Kitab Undang-Undang Hukum Pidana - serta Komentar-Komentarnya Lengkap Pasal Demi Pasal, 1976, Politea, Bogor;

Soerjono Soekanto dan Sri Mamudji, Penelitian Hukum Normatif-Tinjauan Singkat, Radja Grafindo Persada, Jakarta,1985;

Sudarto, Hukum dan Hukum Pidana, 1986, Alumni, Bandung;

Wirjono Projodikoro, Asas-Asas Hukum Pidana di Indonesia, PT. Refika Aditama, Bandung, 2003; 